\title{
Entidades e Massas de Compostos lónicos UMA PROPOSTA
}

\section{Carlos Corrêa *}

Num exercício, num dos nossos livros de Química, pedia-se o cálculo das massas moleculares relativas do peróxido de hidrogénio e do hidróxido de potássio. Uma colega amiga, ao fazer a revisão do livro, notou que o hidróxido de potássio, sendo um composto iónico, não era constituído por moléculas individualizadas e que, por isso, não se devia falar em massa molecular.

A colega tinha toda a razão, mas em português não se dispunha de um termo apropriado para substituir o de "massa molecular".

A IUPAC [1], ao tratar da unidade de quantidade de substância/quantidade de matéria, a mole, considera vários tipos de "entidades" elementares: moléculas, átomos, iões e "formula units". A "formula unit" é uma entidade especificada como um grupo de átomos, tal como uma fórmula química, e não é necessariamente uma partícula real individualizada.

Assim, para o cloreto de sódio, a "formula unit" é $\mathrm{NaCl}$ (fórmula empírica). Poderiamos, se fosse conveniente, considerar a entidade " $1 / 2$ de $\mathrm{NaCl}$ ", tal que

$$
n[1 / 2 \mathrm{NaCl}]=2 n[\mathrm{NaCl}]
$$

No passado, para os compostos iónicos, utilizavam-se os termos "fórmula-grama", "molécula-grama" e "átomo-grama" mas a introdução da mole tornou estas designações desneces-

\footnotetext{
* Professor Catedrático Jubilado da Faculdade de Ciências co Porto
}

sárias (por isso foram abandonadas). Na literatura inglesa, a massa correspondente a uma "formula unit" é designada por "formula mass". Assim, a "formula mass" relativa do cloreto de sódio obtem-se pela soma das massas atómicas relativas do cloro e do sódio. No entanto, a IUPAC [2] não faz qualquer referência a "formula mass". Na literatura alemã usa-se geralmente "Formelmasse".

Em Portugal não se utilizam quaisquer designações que permitam ultrapassar o problema com que iniciamos este artigo, pois só existe a designação de "massa molecular". Utilizar os termos que resultam directamente do inglês ou do alemão, "formula-unidade" e "fórmula-massa" não nos parece apropriado, pois são termos desprovidos de significado. Alguns colegas brasileiros[3], que facilmente importam novos termos, utilizam "massa fórmula".

A primeira ideia que tivemos foi a de utilizar o adjectivo "formular", mas o adjectivo "formular" parecia-nos estranho, embora no Dicionário da Língua Portuguesa da Porto Editora (1994) constasse como adjectivo "relativo a fórmula". Uma consulta ao site "Ciberdúvidas da Lingua Portuguesa" contribuiu para aceitar o termo: "Trata-se de um adjectivo relativamente recente na língua, uma vez que no referido dicionário [Dicionário Houaiss] a datação atribuída é de 1981". Posteriormente, encontrámos na literatura francesa a designação de "masse formulaire" [3].

Assim, propomos as designações de unidade formular e massa formular para substâncias em que não existem moléculas individualizadas, como nos compostos iónicos e nos compostos covalentes de estrutura tridimensional.

\section{Exemplos:}

Às entidades formulares $\mathrm{NaCl}$ e $\mathrm{SiO}_{2}$ correspondem as massas formulares relativas $M_{r}(\mathrm{NaCl})$ e $M_{r}\left(\mathrm{SiO}_{2}\right)$ obtidas pela soma das massas atómicas relativas dos respectivos átomos.

\section{REFERÊNCIAS}

[1] "IUPAC Quantities, Units and Symbols in Physical Chemistry", Second Edition (Green Book), Blackwell Scientific Publications, Oxford, 1993, pags. 41 e 46.

[2] Ref. [1] e versão interactiva de "IUPAC Compendium of Chemical Terminology (Gold Book)".

[3] http://www.mundoeducacao.com.br/ quimica/massa-molecular-massa-formula.htm (Mundo Educação, acedido em 30 de Março de 2009).

[4] a) http://www.rpn.ch/lddr/chimie/ Telechargements/DF/Stoechiometrie.pdf (RPN-Le Portail Pédagogique Neuchâtelois)

b) Carole H MacQuarrie, Donald Mcquarrie, Peter A Rock e C. Jung, "Chimie Générale”, De Boeck Université (2000), tradução francesa da $3^{a}$ edição americana, pag. 185 .

\section{Actualidade Científica}

\section{HoRMONA CEREBRAL DESEMPENHA} PAPEL NO VÍ́CIO - $O$ BLOQUEAMENTO DE UM RECEPTOR DE HORMONA PODE REDUZIR O DESEJO POR COCAÍNA

Novas descobertas sobre um péptido produzido no cérebro podem conduzir a um novo tratamento contra a dependência das drogas.
O péptido é uma hormona concentradora de melanina $(\mathrm{MCH})$, um estimulante natural do apetite. Grandes quantidades de receptor desta hormona, MCH1R, são encontradas num região do cérebro que ajuda a controlar os comportamentos associados a recompensa e motivação. Olivier Civelli da Universidade da Califórnia, Irvine, desenvolveu a ideia de que $\mathrm{MCH}$ e o seu receptor participariam na dependência. Este investigador e os seus colaboradores descobriram que uma molécula designada por TPI 1361-17 podia impedir a ligação de $\mathrm{MCH}$ ao seu receptor. Usando esta molécula, estes investigadores descobriram agora que o sistema $\mathrm{MCH}$ ajuda a contro- 
lar o comportamento de dependência em ratos (Proc. Natl. Acad. Sci. USA, DOI: 10.1073/pnas.0811331106). Injecções de TPI 1361-17 no cérebro dos animais de teste reduzem o uso de cocaína e a reincidência.

Aparentemente, a molécula de TPI 1361-17 não atravessa a barreira sangue-cérebro, pelo que não é adequada para tratar a dependência das pessoas. Contudo, está em curso o desenvolvimento de outros bloqueadores de $\mathrm{MCH} 1 \mathrm{R}$, em especial para aplicações em perda de peso, e estes podem ser testados para tratar a dependência



TPI 1361-17 da cocaína. Esta descoberta é muito importante porque as farmacoterapias anteriormente desenvolvidas dirigiam-se a percursos biológicos centrais a outros comportamentos além da dependência originando efeitos secundários indesejáveis.

(Adaptado de Chemical \& Engineering News, 1 de Abril, 2009)

\section{Actualidade Científica}

\section{DeCRÉscimo da taXa de CALCIFICA- ÇÃO NOS RECIFES AUSTRALIANOS}

Um estudo de grande escala efectuado na Grande Barreira de Coral da Austrália por Glenn De'ath e colaboradores, descrito na revista Science de 2 de Janeiro, demonstrou um enorme decréscimo do crescimento dos corais. A taxa de absorção de cálcio da água do mar pelos corais para calcificação dos seus esqueletos diminuiu enormemente nos últimos 20 anos.

Glenn De'ath e colaboradores descobriram que as taxas de calcificação aumentaram 5,4\% entre 1900 e 1970 mas diminuiram $14,2 \%$ de 1990 a 2005. Os dados recolhidos mostram que a calcificação pode estar a ser modificada com o aumento da temperatura e da acidez dos oceanos.

Este estudo parece suportar as preocupações de que um aumento do dióxido de carbono no ar esteja a colocar em risco estes ecossistemas marinhos.

Os corais começam como larvas de corpo mole que se fixam em superfícies duras e captam compostos de cálcio dissolvidos na água para formar um esqueleto rígido. Um recife resulta da formação destes esqueletos rígidos por colónias de corais.

Para contrariar os efeitos da erosão, a calcificação deve ser suficientemente rápida para compensar as perdas por acção das ondas e de outras forças.

Contudo alguns peritos em corais acreditam que a duplicação do teor de dióxido de carbono na atmosfera nos próximos 50 anos possa tornar impossível a manutenção deste balanço.

Alguns estudos realizados em laboratórios sugerem que com a diminuição do $\mathrm{pH}$ da água do mar ocorre uma redução da taxa de calcificação dos corais. Contudo, um estudo recente sobre o efeito do aumento da acidez da água do mar não parece suportar esta conclusão.

Alina Szmant e colaboradores realizaram um estudo em que usaram ácido clorídrico para aumentar a acidez da água e verificaram que ocorria uma redução da calcificação.

Estudos posteriores mostraram contudo que uma redução quer do $\mathrm{pH}$, por acção do dióxido de carbono, quer da concentração de carbonato de cálcio (resultante de uma aumento de acidez e que se considera essencial na calcificação) não provocava uma redução da velocidade de crescimento dos corais.

A diferença entre estes resultados foi interpretada como indicando um papel crucial do bicarbonato de cálcio. 0 ácido clorídrico e o dióxido de carbono têm efeitos diferentes na química da água do mar e na concentração de bicarbonato de cálcio.

Contudo, qualquer que seja a causa directa, estes novos resultados são motivo de preocupação.

(Adaptado de E. Pennisi, Science 2 de Janeiro de 2009). 